\title{
O que a filosofia cristã pode dizer sobre a globalização e o capitalismo
}

\section{Considerations of a critical philosophy and christian about the globalization capitalized}

\author{
Otávio Barduzzi Rodrigues da Costa $^{1}$
}

\section{Resumo}

Esse artigo pretende traçar algumas considerações filosóficas sobre religião, capitalismo, modernidade e globalização. Para tanto vai realizar uma critica reflexiva do quadro mundial globalizado e o papel que a religião está tendo nessa configuração mundial. Utilizando das ideias de autores do calibre de Assman, Hinkelammert, Ferretti dentre outros mostraremos os mitos pela qual a sociedade globaliza resolve se configurar e mostrar o papel da religião e do ser humano nesse quadro de modo filosófico.

Palavras-chaves: Religião. Capitalismo. Modernidade. Globalização.

\begin{abstract}
This paperwork intends to trace some philosophical considerations about religion, capitalism, modernity and globalization. To this end will make a reflexive critique of the globalized world scenario and the role that religion is having this global setting. Using the ideas of authors in some quality of Assman, Hinkelammert, Ferretti among others, will show the myths by which society decides to configure globalization and the role of religion and human race in this philosophical way.
\end{abstract}

keywords: Religion. Capitalism. Modernity. Globalization.

\footnotetext{
${ }^{1}$ Doutorando no Programa de Ciências da Religião da Universidade Metodista. Professor de sociologia da Universidade Metodista e do IFSP, campus São Paulo. E-mail: adv.otavio@ymail.com
} 


\section{Introdução}

A modernidade tem como ultima configuração a globalização, uma forma de mercado em escala mundial que se propagou em uma forma de imperialismo. Agora a configuração do mundo, bem como seu direcionamento é o capitalismo, tal fato atingiu a religião como um raio; isso porque agora o que satisfaz as necessidades humanas não mais Deus e sim o capital. Segundo Franz Hinkelammert (2008, prefácio) a humanidade se encontra perdida em um labirinto sem saída e a religião verdadeira pode fornecer ao homem um de Ariadne ${ }^{2}$ para a saída desse labirinto (BINI, 2007). O capitalismo e religião são duas fundamentais estruturas pelas quais as relações humanas se basearam na sua visão de mundo e que serão estudadas nesse trabalho.

Com o advento do capital globalizado, suas estruturas comunicantes, sua promessa de felicidade (que não passa de um novo paraíso prometido) o homem se preocupa mais em ganhar dinheiro do que com os desuses ou Deus. Principalmente esqueceuse da mensagem do Deus que se fez homem e veio para o homem no primeiro século. Agora o Deus que existe é o homem, não é um Deus que veio para o homem, mas sim o próprio homem virou Deus, é e isso que construiu o labirinto a qual se refere o ilustre alemão. Ou seja, o homem criou um labirinto donde não vê saída pra si, A figura de um labirinto é apropriada, pois significa que o homem está sozinho na escuridão, sem Deus estamos sozinhos, o monstro não é o minotauro, mas a injustiça socioeconômica que mata quem se aventura no labirinto. Porém esse não é um labirinto que se escolhe se aventurar, a própria besta criada pelo homem, o seu capital é um monstro que devora milhares de vítimas inocentes excluídas pela concentração de renda e ganância.

Antes da modernidade, ainda que com sérios problemas sobre liberdade, Deus era a referencia do ser humano. A Religião era um guia de mundo, uma visão pela qual o homem se pautava, mas agora o homem caminha só, sem um guia, uma referencia de mundo que não seja ele mesmo. O principal orientador que é Deus, o próprio homem dispensou.

Ainda é bom lembrar que Hinkelammert (2008), faz referencia ao mito de Prometeu ${ }^{3}$, segundo o autor esse mito é um dos grandes mitos da modernidade, formula o espaço mítico da modernidade e aparece nos pensamentos críticos sobre a mesma. Marx relaciona o mito de prometeu a uma libertação do proletariado, do homem que trabalha. $\mathrm{O}$ mito de qualquer maneira é visto como uma emancipação e rebeldia do homem frente aos deuses. A conseqüência dessa rebeldia causa a: a autoconsciência humana, entendida como a consciência de ser consciente, está por sua causa outra conseqüência, agora é o humano sua própria divindade suprema. Antes de Marx, Hegel (1970) já falava de uma autoconsciência humana, o ser humano despertou em seu espírito, não precisando mais das

\footnotetext{
${ }^{2}$ Conta a mitologia grega que Ariadne, a filha do rei Minos, ajudaria Teseu, herói grego, a enfrentar seu irmão bastardo e monstro o Minotauro, se Teseu prometesse casar com ela. Teseu reconheceu aí a única chance de vitória e aceitou. Ariadne, então, deulhe uma espada mítica e única que poderia derrotar o monstro e um novelo de linha que não tem fim (Fio de Ariadne), para que ele pudesse achar o caminho de volta dentro do labirinto do Minotauro, do qual ficaria segurando uma das pontas. Significa um apontar de saída para um labirinto cheio de perigos. (BINI, 2007).

${ }^{3}$ Basicamente o mito diz que homens e mulheres eram seres primitivos, vivendo da caça e coleta. Desconheciam o fogo, por isso comiam a comida crua, e embrulhavam-se em peles espessas para se defenderem do frio do Inverno. Não sabiam trabalhar os metais para fazerem ferramentas ou armas duradoiras. Zeus preferia que eles continuassem assim, porque de outra forma receava que alguns viessem um dia a querer roubar-lhe o poder. Mas o sábio Prometeu amava a Humanidade e sabia que com a sua ajuda os homens podiam progredir, saindo do seu estado primitivo. Prometeu foi em segredo ao Olimpo e roubou o fogo dos Deuses entregando aos humanos. Com a ajuda de Prometeu, o homem desenvolveu-se rapidamente. Ficando assim independente dos deuses. Zeus estava furioso e mandou levar Prometeu para uma das montanhas de leste e acorrentá-lo a uma rocha. Uma águia feroz ia todos os dias comer-lhe o fígado, e todas as manhãs o fígado tornava a crescer, de forma que a tortura recomeçava. Passaram-se muitos anos antes de Prometeu ser liberto - dizem que trinta mil - até que o valente Hércules que o libertou. (BINI, 2007). Claro que essa é uma das inúmeras versões que existem do mito mas ele significa que os homens se tornaram independentes do Deuses através do seu trabalho.
} 
divindades, mas sujeitando-as a razão humana. O que se entende que a razão, produto e característica do humano diminuiu Deus, cuja característica deveria ser a incompreensibilidade está desde Hegel sujeita a razão humana.

O mito prometeiano tem um fundo de verdade, o triunfo da técnica (por sinal produto da razão), na qual tecnologicamente e cientificamente, a modernidade fez o homem tornar-se providência para si mesmo, e hoje, para acabar com a fome, as doenças, as inundações, as epidemias, agora não recorre a Deus, ou deuses, como faziam seus antepassados, mas sim à medicina, à engenharia, à indústria, etc. A modernidade proporcionada pela tecnologia, que mitologicamente atribuída a Prometeu é ao mesmo tempo em que é um período histórico indefinido, é uma crença na certeza do cientificismo e da racionalidade, na qual as relações sociais são mudadas.

O ponto alto da modernidade é perceptível com a confirmação de Marx de que não existe Deus e o homem se torna sua divindade suprema. Vale apontar que, no livro "idolatria do mercado", escrito por Hinkelammert com Hugo Assmann (1989) denunciam o resultado do mercado é hispóstases, ou seja, sua suprema personalização-atribuição como agente autônomo. A esse agente é aplicado fé em sua total confiança (GIDDENS, 2002, p. 127) de modo a pensar que nada vai dar errado. Com tal fé no mercado, os homens poderiam atribuem a ele uma confiança ilimitada, ou seja, uma divindade que pode resolver todos os problemas humanos. Ademais, esses autores apontam que o neoliberalismo tem um sistema de apoio dominar a vontade humana, o mercado poderia ser uma "lavagem cerebral" real em profunda consciência do ser humano. Quando a fé no paradigma do mercado poderia sobrecarregar a mente e o coração, a solução dos problemas sociais foi geralmente deixada ao próprio mecanismo de mercado (ASSMANN; HINKELAMMERT, 1989).

Deus se faz homem, na cultura cristã nossa leitura aponta para um conflito entre o deus libertador que se fez homem por querer uma aproximação de sua criação. Já o homem que se fez Prometeu para se afastar de Deus, entendendo que isso iria se autolibertar. A própria configuração da religião cristã ocidental se tornou algo digno de ser combatido e uma prisão do qual o homem deve escapar. Essa opinião é apontada observada por Las Casas (FREITAS NETO, 2003) quando o autor reflete sobre a dominação espanhola e portuguesa sobre as Américas e o sangue que isso trouxe. Ocorre que o homem deveria ter se libertado da religião não de Deus, porém ao libertarse na modernidade da religião rompeu-se com Deus e ao que parece é o homem se faz Deus agora.

Essa visão de que Deus tornava o homem preso é errônea, o que na verdade o homem queria se libertar é do próprio homem, é da religião humana de mortais que queriam se auto-proclamar porta voz da divindade. Com isso distorceram segundo seus interesses a mensagem divina, se confunde a mensagem de Deus com os de muitos corruptos mediadores (PONDÉ, 2001), e assim o ser humano na verdade quer se libertar de outros homens, acaba se separando de Deus. Com isso se torna um ser humano ridículo (PONDÉ, 2001), vazio de origem, sozinho no universo sem algo que explique sua origem e seu papel no universo. Não aceita uma consciência externa superior e externa ao próprio humano. Deus é reduzido a religião como manifestação social esvaziando de significado a divindade. O professor Diego Klautau analisando a obra de Pondé diz:

\begin{abstract}
A redução do fenômeno do religioso em suas formas psicológicas ou sociais é a base da crítica religiosa ao pensamento moderno. Assim, ao aprofundar a epistemologia das mediações, Pondé entende que a crítica religiosa pode se valer dessas mediações para atingir o projeto falido da contingência do homem auto-sustentável, seja essa sustentação de um projeto ético-político, seja na falência, ou insuficiência, de atingir a felicidade. A liberdade pós-adâmica se traduz numa nova expulsão do Paraíso. Sem Deus, não há alívio, não há trégua no tormento humano, que em si mesmo é vazio. (KLAUTAU, 2007, p. 136).
\end{abstract}

Assim a religião é reduzida a compreensão social, econômica, científica, reduzida a ciência, só esse 
entendimento cientifico é aceito segundo as ciências do homem, antropologia sociologia, historia e afins, na verdade um pensamento humano que sempre reduz a uma única compreensão cientifica desprezando outras formas de conhecimento. Comete-se assim o reducionismo cientifico do pensamento divino. Perde-se o significado da transcendência nesse reducionismo (LEPARGNEUR, 2004, p. 98), a ciência é um produto da modernidade. E a Modernidade ao mesmo tempo que é um período histórico (indefinido), é uma crença na certeza do cientificismo e da racionalidade, na qual as relações sociais são mudadas, há uma limitação das formas de conhecimento de que só a ciência formal é valida.

A visão de mundo no moderno e em sua crise - o pós moderno - foi a certeza de que o mundo devia ser visto através de uma lente racionalizada e cientificista, na qual Deus ou a teologia não teriam lugar, ocorre que essa visão falhou fragorosamente em termos sentimentais porém teve o sucesso em conquistar o mundo.

Em primeiro lugar falhou em sua própria certeza, as ideias Popperianas, a crise de paradigma de Khun, o fim das certezas de Prigogyne, bem como de outros cientistas como Feyerabend, Richard Rorty, Maturana e Morin, demonstraram que o racionalismo poderia ser questionado e que haveria nova possibilidades de um nova consciência ser descoberta. Ora o mundo na modernidade só pode ser valido pelo aquilo que poderia ser dado em um gráfico matemático através do que Morin (1994) chama de paradigma newtonianoBaconiano-Cartesiano ou grande paradigma do ocidente.

O Dr. Vitor Westhelle (1995, p. 263) analisando essa questão diz: "Alem disso algo que o mundo moderno proporcionou são as múltiplas "leituras da vida" através de formulas matemáticas e físicas. As coisas se tornam uniformes, [...] com figuras diagramas, lista e texto [...], observa ainda a pergunta de Latour (apud WESTHELLE, 1995, p. 267): "Que sociedade é esta onde uma formula matemática tem mais credibilidade do que qualquer outra coisa: o senso comum, outros sentidos alem da visão, uma autoridade política ou mesmo as escrituras?" A ciência se torna uma forma hegemônica de conhecimento é o que é valido, e conhecimento se torna poder econômico, economia se torna números e gráficos. Assim, nesse mundo moderno coisas abstratas são consideradas menos importantes como Deus, Amor, arte etc... Assim a ciência, um conhecimento humano, de modo pedante, se coloca como única verdade disponível no universo rompendo com a religião e erroneamente com Deus causando uma crise no modo de conhecer o mundo sem precedentes.

\section{A Transformação de Prometeu em Adam Smith}

O homem, representado pelo Prometeu do velho Marx grita e rompe "odeio aos deuses" e envolve Deus nessa sua revolta rompendo com Ele. Ao romper-se torna-se seu próprio Prometeu: autoconsciente, auto-suficiente, auto-referente e independente de toda autoridade religiosa, política e conseqüentemente teológica, situação da qual o homem não precisa mais de Deus. Ao romper com o mito Greco - romano com o grande mito de Prometeu, o homem deixa de se libertar de si e procura se libertar de Deus.

O Prometeu de Marx apresenta um ser humano humilhado, depreciado, abandonado e subjugado, e um ser preso a maquina de trabalho, torturado por uma águia mandada pelo opressor (no mito Zeus, agora o seu supervisor $)^{4}$. Porém de fato há um novo objeto de adoração criado e criatura pelo próprio homem, o homem agora adora a si mesmo, mas ao

\footnotetext{
${ }^{4}$ A comparação da Águia com o supervisor é apropriada, uma vez que os gerentes, engenheiros e supervisores segundo a teoria marxista, são os vigilantes do oprimido em seu trabalho, lembra-se que a águia tem uma visão muito aguçada e, no mito, devora o fígado do trabalhador, aquilo que ele da o sangue para produzir sofrendo com isso.
} 
invés de libertar-se escraviza através do seu novo Deus, que é produto do próprio homem: O mercado.

$\mathrm{Na}$ intenção de livrar-se da religião acusando-a de estar de acordo com a exploração do homem pelo homem, comente um erro, desconsidera de que a religião era produto humano e não divino. Por causa digo, não se nega que a religião tenha trazido certa exploração, porém só o fez quando contaminada pela política e economia, ou seja foi império corrompido pelo homem. Não se pode negar isso, quem em sã consciência afirmaria que, por exemplo, a inquisição ou o terrorismo irlandês seja a mensagem de amai-vos uns aos outros? A ciência veio supostamente oferecer a racionalidade ao mundo. Ter relações pautadas pela racionalidade (hegemônica no ocidente) não era uma oferta tão ruim frente a uma ideia da idade média, de um absolutismo rigoroso e de uma crueldade cristã. Porém o projeto da modernidade se mostrou tão senão mais cruel do que a idade média. Temos liberdade, porém temos outros problemas. Uma delas é a própria liberdade, a qual o homem escolheu certas opções erradas.

Passa a escolher as liberdades econômica, a principal liberdade pedida pelos direitos humanos, isso da uma liberdade ao mercado e uma liberdade do homem explorar o homem. Em meados do século XX passa a acontecer uma terceira revolução na Europa, a Revolução Industrial, a burguesia inglesa que havia adquirido poder político passa a promover no país transformações econômicas e sociais. De agora em diante era o capitalismo industrial que mandava no mundo.

O mercado passa a ser sacralizado. O mercado desde Adam Smith passa ser visto como um ser autoconsciente e que se regula como se tivesse vontade e razão (FLEISCHACKER, 2004, p. 85), em uma leitura particular, um reflexo do próprio ser humano, uma divindade mais parecida com a ganância do ser humano, um seu reflexo; não mais imagem e semelhança de Deus mas de si mesmo. Um dos quadros desse livre-mercado é a concorrência, uma lógica de se derrotar e se sobrepor aos outros que perfaz uma ética do sujeito destrutiva e competitiva. Assim a liberdade suprema do mercado não pode ser limitada ao outro, formase uma ética do sujeito de uma liberdade ilusória, uma liberdade que na verdade escraviza garantidas por leis que supostamente trariam liberdade.

A lei existe para preservar os valores que um grupo social considera importante, tais valores não são imutáveis, uma vez que a sociedade pode mudar seus gostos e valores através da história, confirme a evolução das ideias humanas. Os valores de uma sociedade são aquilo que ela, como equilíbrio de interesses considera como valioso expressado em um texto legislado. Este texto legal manda ou proíbe algo em consonância com a justiça e para o bem da sociedade no seu conjunto, preservando o que ela considera valiosa. Por exemplo: "A venda de cocaína é penalizada pela lei”, "A lei proíbe que uma pessoa mate outra", "Um homem nunca deve roubar outrem". No caso tal sociedade considera a luta contra as drogas, a vida, a propriedade privada como valiosas.

Pode-se dizer que as leis limitam o livre arbítrio dos seres humanos que convivem em sociedade. Funcionam como um controle externo ao ato humano que rege as condutas (os comportamentos). Se uma pessoa considera que não tem mal em adotar uma determinada ação, mas que esta é punida por lei, terá tendência em abster-se de o fazer independentemente daquilo que achar pessoalmente. Exemplo uma pessoa precisa de um "Tablet" vê um ao lado que o colega de faculdade esqueceu, não vai se apropriar do objeto ilegalmente, pois ha uma lei que o proíbe.

Existem varias fontes de leis e do direito e uma delas é a religião, visto que a religião divulgaimpõe valores. Vai emitir opiniões que as pessoas que a seguem ou que a simpatizam com ela tomarão como importantes na sua vida social. No âmbito sócio - político, a lei é um preceito ditado por uma autoridade competente. Para Marx a lei vai ser uma 
prisão e de fato: Se ela protege o que é valioso em uma sociedade nossa sociedade tornou valioso a propriedade privada, o capital, a livre concorrência, tudo isso protegido por lei que em vários casos se torna uma prisão.

Tal prisão garante a existência de um sistema utópico chamado mercado, sobre ele é criado um mito, o mito que deveria resolver todos os problemas humanos mas não o faz pois isso é utopia (HINKELAMMERT, 2008, p. 45). A globalização nova forma de mercado só exclui e escraviza cada vez mais o homem. Crer na justiça do mercado é uma razão mítica - utópica - impossível, pois tal sistema não pode trazer salvação. Ao contrario, só tem trazido escravização (POULANTZAS, 1968, p. 26).

Assim se faz necessária uma nova ética do sujeito (HINKELAMMERT, 2008, p. 47), uma agir do sujeito sobre o mundo. O autor propõe que uma teologia da libertação, possa ser a solução, não um rompimento com Deus mas com aquilo que oprime o homem, um novo ecumenismo. A resposta para esse problema talvez esteja na proposta de um nova Religião, digamos uma religião esclarecida (se é que isso é possível), um que proponha como fundamentos de sua religiosidade as ideias que não produzam vítimas (CERTEAU, 1998), onde o fundamento das configurações cristãs seja a o amor ao próximo; das judaicas, o relacionamento com Yavhé e da sua benignidade, das mulçumanas do caminho do servir sem escravizar e da bondade. Ou seja, que seus fundamentos sejam os condizentes com as conquistas de direitos humanos conseguidas a muito custo pelo Estado democrático, e da promoção de um Estado Laico que garanta o respeito as culturas e a liberdade religiosa.

\section{Os Novos Mitos}

Segundo Hinkelammert (2008, p. 47), os mitos antagonizam a razão instrumental, porém a razão instrumental vive, quando do seu interesse, certos mitos tal como a mão invisível do mercado. O autor afirma que a modernidade cria mitos e são contra os mitos que se confundem com religião. São contra os mitos gregos, mas criam mitos como o do progresso, do crescimento patológico, da democracia racial, da igualdade de oportunidade de igualdades, da verdade absoluta da ciência (que pretende explicar tudo) e vive segundo esses mitos. Os mitos segundo Campbell, são as historias que conduzem nossas vidas, "Mitos são pistas para as potencialidades espirituais da vida humana" (CAMPBELL, 2007, p. 14) assim esses mitos, sobretudo o do progresso, é o que tem pautado a sociedade moderna. Não importa quem exclua ou quem deixe ferido, essa é a certeza que tem pautado nossa sociedade assim os sofrimentos e exclusões são justificados porque alguém disse que é assim que os mundo deve funcionar, é a própria essência do mito.

Um deles é que a ciência e o seu produto comercializável, as tecnologias, que foram apropriadas pelo capitalismo para gerar dinheiro tem as potencialidades para resolver todos os problemas humanos. De comunicação à depressão, da produção material à fome, da impotência sexual ao deslocamento espacial, a tecnologia quer resolver todos os problemas, as vezes até os espirituais e emocionais através de remédios caros e globalizados.

A habilidade e a facilidade com que o homem cria técnicas sempre novas e mais perfeitas provocou nas gerações recentes uma confiança sem limites no progresso humano, nas possibilidades de levá-lo à frente até a realização do paraíso na terra e à feliz solução de todos os problemas e mistérios do homem. Mas é realmente verdade que as ciências e a técnica têm o poder de resolver todos os problemas e enigmas humanos? Não tem.

Aliado a toda manutenção de conhecimento único, surge a ideia de que conhecimento é poder (WESTHELLE, 1995) e que esse poder foi jungido ao capital e serviço desse, ou seja a ciência foi 
submetida ao "interesse do capital" (PANIKKAR, 2005, p. 20), sendo assim o poder ao qual se refere Marcuse (1973) é em sua critica a modernidade é o próprio capital. Para entender o trunfo do capital sobre os valores antes religiosos, houve um triunfo da comunicação que trouxe e confirmou a modernidade e propôs sua própria crise.

Surgiram, no seio da modernidade, novas tecnologias da comunicação, produtos dessa ciência racionalizada, que levou o homem a um movimento de consumo desmedido e capitalizado. As pessoas passaram a ser valoradas não pela sua essência, e sim pela sua capacidade de consumo. Termos antes caros a humanidade como a teologia como alma, bondade, caridade não tiveram mais lugar.

A modernidade a tudo racionaliza. A tudo matematiza, a tudo contabiliza, a tudo registra de tal maneira, o homem fica reduzido a um negócio de contabilidade, que interessa particularmente aos registros das taxas e dos seguros (Steuerug und Sicherrung), para utilizar uma expressão de Heidegger (2007, p. 113). A razão dita racionalizada que serve para equilibrar o mercado, nunca produziu tanta loucura, quem não se encaixa no sistema e tem uma crise é considerado louco. Esse suposto diagnóstico so serve aos interesses do sistema de poder político e econômico estabelecido (FOUCAULT, 1972).

Hinkelammert (2008, p. 57) remete a uma frase de Goya "a razão ao sonhar produz monstros", visto que a razão não sonha: planeja, não abstrai: calcula. A razão substituiu as necessidades humanas pelas preferências do mercado (HINKELAMMERT, 2008 , p. 58). Nem a morte pode se discutir mais A modernidade criou segundo Giddens (2002, p. 9) certo sequestro de experiências, ou seja, através do sistema auto-referenciado de conhecimento e de poder separa-se da vida certos conhecimentos naturais, como enfermidade loucura, criminalidade, morte, sexualidade. São direitos raptados e postos a serviços da racionalidade e da garantia de pagamento civil.
As garantias de direitos humanos foram cooptadas por direitos que na verdade só garantem a globalização do mercado, a propriedade privada e a miséria e morte dos excluídos. Embora o mundo possa reagir e enfrentar tais problemas, quem enfrenta leva a peja de terrorista e criminoso e outra vez combatidos por leis que só atendem as necessidades globalizantes.

Ë criado um mito do poder, um dos vários mitos pela qual a sociedade humana se configura, assim como o mito do sucesso, do crescimento patológico, da mão invisível, do capital justo etc ..., ocorre que a mesma modernidade que não considera verdade os mitos antigos gregos se fundamenta e se relaciona nesses novos mitos. O que é pior mitos protegidos pela lei e pelo suposto estado democrático de direito. São os mitos modernos. Mitos que direcionam a visão da sociedade, o do crescimento ilimitado patológico (que causa problemas mentais e ecológicos), o da democracia racial(ledo engano), o da igualdade de oportunidades e de direitos(igualdade? Onde?), o da liberdade(apenas para consumir) o do livre-mercado(como se fora possível ele estar livres de forças que o dominam) etc... apesar da sociedade viver todos esses mitos, despreza os mitos fundantes de uma melhor visão de mundo.

O próprio cristianismo, o Deus que se fez homem é considerado um mito e ridicularizado porém se utilizam vários mitos para parametrizar a modernidade. Deus deixa de ser a reposta e se transforma em um homem, um semelhante (HINKELAMMERT, 2008, p. 73) criando de certo modo o cerne da modernidade: o humanismo, agora é o ser humano, e não Deus o centro do universo. $\mathrm{O}$ cristianismo nasce com uma teologia da Culpa, da dívida e do perdão e nasce daí uma nova religião, uma religião sem culpa - o capitalismo.

Benjamin (1987, p. 69) evoca, os termos "dívida" e "culpa". Segundo numa perspectiva histórica do de que não podemos separa esses dois termos, no sistema da religião capitalista, a "culpa 
mítica" da dívida econômica, surge como algo sem culpabilizaçao. O capitalismo é um culto que não resgata, mas deixa um sentimento de culpa apenas nos sensíveis. Neste sentido, este sistema religioso,surge após o colapso de do cristianismo. Uma enorme sensação de culpa, incapaz de se render, deu proveito a esse culto, e sua culpa, em vez de ser resgatadas é universalizada, gravada na consciência, até que o próprio Deus é preso na rede culpa, de modo que, finalmente, ele próprio está interessado em sua expiação. Não se pode, portanto, esperar que isso aconteça no próprio culto, ou a reforma dessa religião, uma vez que teria de agarrarse a algo sólido que aparentemente não existe na historia (isso seria o verdadeiro cristianismo mas foi rejeitado como mito). A essência deste movimento religioso que é o capitalismo é parte de sua capacidade de percorrer todo o caminho, de fornecer todas as repostas finais, até culpar a Deus, para atingir o estado de desespero no mundo.

O apocalipse cristão pode ser entendido como tradução da visão da historia ocidental, é um dos textos fundantes da sociedade ocidental (HINKELAMMERT, 2008, p. 104). De Hobbes a Locke, de Marx a Engels, de Hegel aos capitalistas, todos compararam o apocalipses as mudanças econômicas e sociais que perpassaram o mundo. Esse texto é usado erroneamente para legitimar as violências ao redor do mundo bem como as injustiças produzidas pela exclusão (ora os cavaleiros do apocalipse são as mazelas do mundo). Essa comparação apocalíptica se torna assustadora demais quando pensamos no fato de que o mundo finalmente tem um poder auto-destrutivo causado pelo capitalismo, agravado pela oposição ao socialismo histórico. O mundo tem ogivas nucleares, biológicas e químicas para destruir a vida na terra mais de 400 vezes (THOMPSON, 1982), o apocalipse é rejeitado como mito, mito que se acredita que não pode acontecer, porém está perto como nunca, o apocalipse impacta alem do cristianismo, e cria um "marco de categoria" do exercício de poder no ocidente.

\section{A Espiritualidade do Mercado}

O dualismo, proposto por Renée Descartes constitui o grande referencial epistemológico do ocidente (MORIN, 1994). Hall (2005, p. 12), lembra que ele postulou duas substâncias distintas — a substância espacial (matéria) e a substância pensante (espírito). Ele refocalizou, assim, aquele grande dualismo que tem afligido a o pensamento filosófico desde então. Até essa proposição não se havia pensado numa oposição entre corpo (matéria) e Espírito.

Ocorre que a modernidade se apresenta mediada por seus meios de comunicação, apresenta uma materialidade extremada, o sucesso, as casas novas, os carros de marca materialmente falando são a representação de algo espiritual, a felicidade que não pode ser alcançada por todos. Cria-se um mito do progresso, que se apresenta como uma nova espiritualidade (HINKELAMMERT, 2008, p. 109) ainda que baseada em materialidade. Assim o que é material é valorizado e o que é espiritual é deixado de lado ainda que baseado no grande mito do ocidente: o mito do progresso.apena há um interesse material aquilo que é espiritual não é reconhecido como verdade, (LIMA VAZ, 1992, p. 105) e sim como mito, a própria noção de mito é reduzido a algo mentiroso ao invés de uma interpretação de mundo.

Em certa divagaçao Hinkelammert (2008, p. 113) inicia e com uma frase bem emblemática "o Capitalismo surge com a pretensão de ser a instância de salvação", atribui o começo desse ao mercantilismo exploratório colonial, porém sua ideologia à obra de Adam Smith. Acusa seriamente que a as posições cristas dos primeiros séculos eram ao contrario fazendo uma explanação teológica de Mateus 6:24 com a citação de Jesus : "Não se pode servir a Deus e a Mammon". Porém o que ocorreu foi ao contrario ocorreu uma espiritualidade do mercado. Hoje é o capital e o dinheiro que promete o paraíso e a felicidade não mais as coisas espirituais.

O mercado, a tudo toma conta e passa a ser o regulador das relações sociais, mais do que isso, passa a ser o centro das sociedades, se infiltrando no dia- 
a-dia das pessoas. A referência passa a ser mercado e recursos, mercado de trabalho, de capitais, de alimentos, da droga, mercado matrimonial, religioso e de bens simbólicos, não há expressão mais assustadora, por exemplo, do que recursos humanos: ou seja, para a produção de bens e serviços o ser humano é reduzido a um recurso, um bem substituível a qualquer momento. Outra expressão odiosa é "regime de bens" num casamento, o casamento algo espiritual, de uma relação sagrada e de amor entre duas pessoas, é reduzido a uma garantia contratual.

A obra de E. Durkhein (2000, p. 261) já afirma que: "não há religião sem comunidade (igreja)". O mercado como religião marca a nova comunidade que é a sociedade moderna. As pessoas se reconhecem e se valorizam pelo poder de compra que tem. Uma pessoa de bem é aquele que tem poder de consumo.

A religião do mercado tem os seus comportamentos e dogmas. Como exemplo:

- O mercado é causa de desigualdades; assim é um produtor de vítimas, que ou são exploradas ou são vitimas da violência causada pela comunicação que leva desejos aos que não podem e por isso roubam violentamente multiplicando as vitimas (MESSNER, ROSENFELD, 2000).

- O mercado dentro da ordem capitalista mundial gera concentração de riquezas na mãos de poucos países e de poucos magnatas e desestruturação social e miséria para as maior parte da humanidade (HOFFMANN, 1994).

- $\quad$ Não é mais a fé que move céus é terra é outra coisa que tem atribuída tal força . O lema fundamental é: "o dinheiro tudo pode, move o céu e a terra".

- A propaganda tem a função de uma felicidade salvífica. Se você não pode ter a mercadoria $X$ você não é feliz. Se você não tem mercadoria e não pode ser bem sucedido portanto é um excluído e não é uma pessoa de bem.

- $\quad$ As mercadorias são representantes de desejos mais profundos da alma.
- A propaganda é uma autentica catequese, um ensinamento do que deve ou não ter para ser feliz.

- O culto dominical são os programas televisivos.

- A grande festa anual é o natal. Não para comemorar o nascimento do Salvador, mas uma festa de consumo e presentes a quais as crianças são educadas desde cedo.

- Os templos são as lojas.

- A peregrinação são as novas viagens; os grandes shoppings e cidades do consumo, e turismo, Disney World, Miami, Paris etc.

- Os sacerdotes são os que conhecem as regras do jogo, advogados, que garantem a propriedade privada e seu pagamento, economistas e banqueiros.

- As vestes rituais para participar da sociedade são as roupas de marca caríssimas tal como Ermenildo Zegna, Nike, Lacoste etc....quando se está vestido assim o ser se torna bem-quisto na sociedade. Quando não veste, é um excluído dela.

- A ética principal é o interesse pessoal, egoísta, competitivo com sede de crescimento financeiro patológico.

Assim, se constrói e produze a religião da espiritualidade do mercado.

Tal religião promete felicidade a todos os que a consomem. Essa promessa falha fragorosamente uma vezque poucos tem o poder de ter tudo o que se apresenta para consumo. As mercadorias tem status divinos e de bênçãos. A elas se adjudicam características salvíficas. É no contanto com o novo sagrado que surge uma nova ética de ser a da competição e concorrência no mercado, seu semelhante passa a ser visto como concorrente. A mística que move as pessoas no capitalismo é ganhar dinheiro para ganhar mais dinheiro; comprar mais, comprar mais para consumir mais e mais. É no poder de consumo, que se mede o caráter de uma pessoa segundo essa lógica. O ser humano é medido em Ter 
e não em Ser. Numa sociedade assim, a pessoa tem a sua dignidade reconhecida nas relações mercantis, no mercado. Os pobres são marginalizados exatamente pela sua impossibilidade de acesso ao mercado. Esses milhares que são a maioria do mundo são invisíveis e reduzidos a mero problemas políticos, seres humanos incapacitados de participar de acesso aos bens que na eles mesmos produzem em um total estado de alienação, alienação do produto de seu trabalho, alienação causada pelo sistema de propaganda. $\mathrm{Na}$ tentativa desesperada de sobreviver e de seus filhos perde-se o amor ao próximo.

\section{Um Deus Humanizado}

As ideias do humanismo que deveriam libertar o homem, na verdade o escravizam quando a maior de todas essas ideias: o mercado livre de controle, inclusive ético, surge.

Ocorre uma divinização do homem e a humanização de Deus (HINKELAMMERT, 2008, p. 107). De como o humanismo trouxe agora na historia que o homem e não Deus era o centro do universo. Disso decorre algumas consequências tal como: propriedade é individual e um direito sagrado, por natureza. A isso o indivíduo leva como algo sacro. Outra consequência é o crescente poder da burguesia, cuja consequência se da a vida pelo comércio, o comércio não mais é um meio de subsistência mas a atividade pela qual as pessoas vivem e morrem e o importante nessa atividade passa a ser o lucro. Assim surge as condições do capitalismo selvagem.

O socialismo surge como uma alternativa teoricamente excelente, mas que historicamente se mostra como incapaz de resolver tais mazelas uma vez que só muda o foco da propriedade ao invés de propriedade individual se fala em propriedade socialista. Alem disso há um grande problema a redução de toda a história e condição humana a luta de classes. Tal concepção marxista é impossível de compreender toda a riqueza da experiência humana.
A globalização vem com um discurso de igualdade entre as nações mas não passa de uma ilusão para mais exclusão e fome (SANTOS, 2008). Essa fase do capitalismo decorre da decisão das potencias emergentes do pós guerra fria de impor ao mundo uma força motriz comercial capitalista que possa dar mais poder as empresas transnacionais. Com essa pratica se da estratégia ao mercado sem controle ou responsabilidade por seus atos.

O mercado disfarça sua finalidade (o lucro) em respeito a certos direitos humanos, porém alcançar a plenitude desses direitos se tornam impossível visto a finalidade do mercado não ser alcançar esses direitos (meio ambiente ecologicamente equilibrado, justiça, saúde, educação pleno emprego etc..) e sim o lucro. Desse modo a finalidade do homem (e não só da empresa) também passar a ser o lucro, impossível não lembrar do epíteto de Hobbes, como nessa lógica pessoal vai surgir o homem: a reposta é apenas como lobo do homem, como concorrente de seu semelhante.

A liberdade humana nessa relação fica ilusória e prejudicada uma vez que o homem só tem liberdade para consumir. Hinkelammert (2008, p. 122), diz da liberdade de escolher entre uma sociedade de plena convivência e uma sociedade Hobbesiana, mas não há como agir sobre tais suposta liberdades frente a força poderosa do capital. O próprio autor diz que a democracia está a serviço do capital (HINKELAMMERT, 2008, p. 132). Não se existe liberdade para se escolher entre igualdade e fraternidade pois isso implicaria em abrir mão da propriedade privada e do lucro o que aparentemente ninguém quer escolher.

\section{A Religião Sem Culpa}

Analisando o texto de Walter Benjamin: O capitalismo como Religião, chega-se a conclusão de que o capitalismo também é uma religião, uma sem culpa. Lembrando da culpa que o povo no deserto, desobedecendo a Moisés, adoraram um bezerro de ouro, mas o homem agora alimentou e adora esse 
bezerro, já crescido e posto simbolicamente no centro do capital, em Wall Street, como um agora, já fortalecido um boi de ouro, o povo agora não sente culpa em adorar ao capital. Como analisa Benjamin, o capitalismo é uma religião na qual o culto se emancipou de um objeto de adoração e passou a ser o seu próprio ato de consumir e não há culpa, tabus, nem pecados ao contrario das religiões, e, portanto, não há redenção há só felicidade prometida (mas raramente alcançada). Então, do ponto de vista da fé, o capitalismo não tem nenhum objeto: acredita no puro crédito no dinheiro a ser alcançado por um lucro que virá.

Há um culto ao dinheiro, o objeto de desejo e de adoração não é algo transcendente mas sim, o vil metal, o Deus se torna dinheiro (AGAMBEN, 2004). No capitalismo não há perdão de vividas há garantias de dividas, que se tornam novos lucros. No capitalismo não se pode pagar com sangue do Cordeiro suas dividas. Também é pouco provável que uma divindade vá pagar as dividas creditícias, disso só decorre a descrença na força de Deus e a crença na força do capital.

A culpabilização da religião Cristã se dá pelo assassinato de Cristo no Calvário, não há culpa no capitalismo apesar de varias vitimas que ele gera por ser uma religião sem responsável pela sua culpa e sem Deus a quem culpar. a religião tem a função de ser o fundamento da cosmovisão que legitima a ordem social vigente, assim o capitalismo como religião legitima a ordem do lucro.

Há um vácuo na objetividade do mundo, que esta no cerne da visão sistêmica de mundo (LUHMANN, 1986) e na inversão dos objetos e do papel do humano, agora sãos os objetos que fazem as coisas. E o dinheiro é quem faz, tira do homem a sua responsabilidade do uso das maquinas e do dinheiro. Esta inversão teórica desculpabiliza o ser humano. O ser humano não é o ser que constrói o mundo em Deus. No capital, o ser humano é um objeto a ser usado, e quem constrói o mundo agora passa a ser o dinheiro em uma inversão da objetividade do agir do homem.

Nessa relação entre parte/parte e partes/todo, a atuação causal, destaca Morin (1987) é a causalidade circular, que atua como um princípio de organização recursiva. Desse modo, as interações entre as partes formam um todo e este "todo" emergente às mesmas e de outras interações, retroage sobre as partes que o constituíram, determinando o modo de ser das partes. A organização recursiva é a organização cujos efeitos e produtos são necessários à sua própria causação e à sua própria produção. É, exatamente, o problema de autoprodução e de auto-organização.

Uma sociedade é produzida pelas interações entre indivíduos e essas interações produzem um todo organizador que retroage sobre os indivíduos para co-produzi-los enquanto indivíduos humanos. Ocorre que a causa de tudo não são mais as relações múltiplas mas sim o dinheiro causa tudo(e não mais Deus) e é motivado pela ganância. A ganância é que dita o como o mundo vai se desenvolver.

\section{Papel do Ser Humano: Servir}

Ao fazer uma análise do mito de Édipo, Freud (1974) termina com o papel de Deus e o coloca como algo horrível, uma opressão um desejo de ser oprimido do próprio homem. E faz uma comparação com Deus pai as interpretações dos cânones freudianos em relação ao Deus pai. No sentido freudiano a religião responderia ao anseio por um pai poderoso que oferece segurança, proteção (poupa os homens de uma neurose individual ao preço de deixá-los num estado de infantilismo psicológico, submetidos ao que chama de um delírio de massa). Freud (1974) afirma que a natureza do homem exige este tipo de controle para que ele possa viver em sociedade. Dessa forma, se a religião fosse extinta, inevitavelmente, o homem criaria outro sistema de doutrinas com as mesmas características para se defender. Ao que parece criou o capitalismo, ou melhor ao invés de uma religião com Pai se transmutou em uma religião sem pai. 
Não é um novo sistema é ainda uma religião, mas sem pai a quem atribuir seus conflitos psíquicos.

Justiniano (2001) em Roma já falava de uma teoria do espelho atribuída a Marx, que afirma que o sistema jurídico é uma reflexo das relações econômicas. Por exemplo quanto a satisfação dos débitos para garantir as divida, já lecionava Gaio (JUSTINIANO, 2001) (Digesto, 27, 10, 5) a ideia de que só deverão ser vendidos os bens do executado que se mostrarem suficientes para a satisfação dos seus débitos. É o princípio da satisfatividade, informativo da tutela jurisdicional executiva previsto no artigo 659 do Código de Processo Civil Brasileiro em varias leis do ocidente. Alem disso as questões de herança eram puramente materiais como nos direito ocidental hoje e não mais patrimônio sentimental ligado ao nome. $\mathrm{O}$ direito sempre teve relação intima ao econômico. O que serve para uma analise do capital como regras imperiais de domino como aponta Jung et al. (2012) pela qual o império capitalista a tudo domina.

Assim nessa lógica elementos de direitos humanos tal como vida e liberdade tem menos valor que a propriedade. Até bem pouco tempo atrás na historia no Brasil e em alguns países ainda persiste, a ideia de se ir preso por dividas materiais, o que da a liberdade um valor menor que a propriedade. Isto para não falar nas violentas retomadas de propriedade abalizadas pelo Estado muitas vezes com mortes a qual se depreende de que a vida tem menos valor do que propriedade.

\section{Concluindo}

O capitalismo usa sua fabrica de guerra e morte, mas tem um fim: o lucro (HARVEY, 2006). Ele supera suas crises com maquinas e mais maquinas de guerra donde se produz mais lucro e impulsiona a indústria, Hinkelammert (2008, p. 193) apontando para a triste inversão de direitos humanos que pretendia Locke, mostra que os direitos não se propuseram a maioria dos homens mas só a elite. Assim o capitalismo e a técnica com sua maquina de guerra assim como sua razão produz monstros como o autor cita a famosa obra de Goya. Esses monstros são produzidos em uma estética de morte, corrupção, invencibilidade e domínio, ou seja, a própria essência da monstruosidade.ainda o capitalismo moderno ao se opor a certos valores produz outros monstros como o fundamentalismo.

O homem, que se deixou seduzir pelo ídolo da técnica, por fenômeno de ressentimento, os despreza e procura a afirmação de si mesmo na vontade de dominação do mundo, não mais visto como um meio para a realização dos valores mais altos, mas como fim em si mesmo: donde a civilização da técnica, o industrialismo e o capitalismo. Ferretti (1972) afirma, analisando as obras de Scheler, o seguinte:

\begin{abstract}
Logo não há mais plenitude de vida, não mais o amor para o mundo e para a plenitude de suas qualidades, não mais a autocontemplação desinteressa como objetivo real do homem, mas cálculo utilitarista com fim em si mesmo, redução da natureza ao seu aspecto exatamente mensurável e seguramente dominável, fanatismo do trabalho e do lucro, avaliação somente das qualidades humanas de diligência, rapidez, capacidade de adaptação, que possuem uma utilidade aos fins lucrativos. O nascimento da ciência moderna e a concepção mecanicista da natureza não são as causas, mas sim os efeitos dessa nova atitude, que consagrou a natureza, privando-a de Deus, da alma, de todo valor e qualidade.
\end{abstract}

Além da perda dos valores do espírito, a ciência e a técnica causaram um desgaste profundo nas relações humanas. Buber (2001) observou agudamente que, com o passar dos séculos, o mundo material se engrandeceu mais e mais, enquanto o mundo das relações pessoais pouco a pouco se restringiu. Um processo é a conseqüência do outro, visto que "o desenvolvimento da capacidade de experimentar e de utilizar cresce com a diminuição da capacidade do homem de criar uma relação dialógica" (BUBER, 2001, p. 65). Hoje, parece que a relação dialógica ficou menor, e que tenha cedido lugar àquela do domínio entre homens e de subjugação entre estes e a natureza e subjugando a próprio Deus. 
Assim vemos de mitos que foram desconstruídos para dar lugar a outros não mais para explicar a vida, mas para subjugar a vida a um sistema cruel de poder. Porém outros mitos surgiram para dar certa razão ao modo de vida moderno, posso fazer uma consideração o mito da caverna de Platão: em nossa sociedade apenas se enxerga o que quer e não percebemos que somos escravos de nosso próprio desejo imposto por um sistema maior que nos prende a nos mesmos. A concepção Cristã nos convida a olhar ao próximo e a transcender nossos desejos em prol de um bem comum. Terminamos citando uma mudança que a bíblia nos convida de deixar a lucratividade e a viver uma ética mais cristã: Filipenses 3:7: "Mas o que, para mim, era lucro, isto considerei perda por causa de Cristo".

\section{Referências}

AGAMBEN, G. Permanente emergência: entrevista. O Globo, Rio de Janeiro, 4 dez. 2004. Caderno Prosa e Verso.

ASSMANN, H., HINKELAMMERT, F. J. A idolatria do mercado: ensaio sobre economia $e$ teologia, teologia e libertação. Petrópolis: Vozes, 1989.

BENJAMIN, W. Magia e técnica, arte e política: ensaios sobre literatura e história da cultura. São Paulo: Brasiliense, 1987.

BINI, E. A sabedoria da mitologia. São Paulo: Edipro, 2007.

BUBER, M. Eu e vós. São Paulo: Centauro, 2001.

CAMPBELL, J. O poder do mito. São Paulo: Palas Athena, 2007.

DURKHEIM, E. As formas elementares da vida religiosa. São Paulo: Martins Fontes, 2000.

FERRETTI, G. Max Scheler, fenomenologia $e$ antropologia personalística. Milano: Vita e Pensiero, 1972.
FLEISCHACKER, S. On Adam Smith's 'Wealth of nations: a philosophical companion. Princeton: Princeton University Press, 2004.

FOUCAULT, Michel. História da loucura na idade clássica. São Paulo: Perspectiva, 1972.

FREITAS NETO, J. A. Bartolomé de las Casas: a narrativa trágica, o amor cristão e a caridade. São Paulo: Annablume, 2003.

FREUD, S. O mal-estar na civilização. Rio de Janeiro: Imago, 1974.

GIDDENS, A. Modernidade e identidade. Rio de Janeiro: J. Zahar, 2002.

HALL, S. A identidade cultural na pós-modernidade. 10. ed. Rio de Janeiro: Ed. DP e A, 2005.

HARVEY, D. A produção capitalista do espaço. São Paulo: Annablume, 2006.

HEGEL, G. W. F. Werke in zwanzig Bänden: theoriewerkausgabe. Frankfurt: Shuhrkamp, 1970.

HEIDEGGER, M. Nietzsche. Tradução de Marco Antônio Casanova. Rio de Janeiro: Forense Universitária, 2007. v. 2.

HINKELAMMERT, F. J. Hacia una crítica de la razón mítica: el labirinto de la modernidade. México: Driada, 2008.

HOFFMANN, R. Distribuição de renda: medidas de desigualdade e pobreza. São Paulo: EDUSP, 1998.

JUSTINIANO, F. P. S. Institutas. Tradução de Edson Bini. São Paulo: Edipro, 2001.

KLAUTAU, D. O conceito de humanismo ridículo proposto por Luiz Felipe Pondé: crítica à modernidade: entre Dostoiévisk ePio IX. Sacrilegens, Juiz de Fora, v. 4, n. 1, p. 134-154, dez. 2007.

LEPARGNEUR, H. Reducionismo científico e abertura à transcendência. Sintese: Revista de Filosofia, Belo Horizonte, v. 31, n. 99, p. 91-105, 2004. 
LIMA VAZ, H. Religião e modernidade filosófica. In: BINGEMER, M. C. (Org.). O impacto da modernidade sobre a religião. São Paulo: Loyola, 1992. (Seminários Especiais, Centro João XXIII).

LUHMANN, N. The autopoiesis of Social Systems. In: GEYER, F.; ZOUWEN, J. (Org.). Sociocybernetic paradoxes. Cambridge: Polity Press, 1986.

MARCUSE, H. A ideologia da sociedade industrial: o homem unidimensional. 4. ed. Tradução de Giasone Rebuá. Rio de Janeiro: Zahar, 1973.

MESSNER, S. F.; ROSENFELD, R. Crime and the American dream. Belmont: Wadsworth, 2000.

MORIN, E. Ciência com consciência. Lisboa: Publicações Europa-América, 1994.

MORIN, E. $O$ método $I V$ : a vida da vida. Lisboa: Publicações Europa-América, 1987. v. 2.

PANIKKAR, R. Morte e ressurreição da teologia. Horizonte, Belo Horizonte, v. 4, n. 7, p. 15-29, dez. 2005.

PONDÉ, L. F. Epistemologia agônica e disfuncionalidade humana: um ensaio de teologia pessimista. REVER: Revista de Estudos de Religião, São Paulo, v. 2, p. 79-95, 2001.

POULANTZAS, N. Hegemonía y dominación en el Estado moderno. Cuadernos de Pasado y Presente, Córdoba, n. 48, p. 112-115, 1968.

SANTOS, M. Por uma outra globalização: do pensamento único a consciência universal. 17. ed. Rio de Janeiro: Record, 2008.

THOMPSON, E. P. (Ed.). Exterminism and cold war. London: Verso/New Left Books, 1982.

WESTHELLE, V. Outros saberes: teologia e ciência na modernidade. Estudos Teológicos, São Leopoldo, v. 35 , n. 3, p. 258-278, 1995. 